эффективности: общие - полно выполненная работа в определенные сроки и специфические критерии у традиционного поколения - принести благо обществу; для переходного поколения - гибкость, умение не оглядываться; для информационного поколения - мобильность, умение меняться.

Таким образом, каждое поколение имеет свои специфические стратегии поведения в конфликтах, сопряженных с определенной степенью лояльности к организации и критерии эффективности.

\title{
Литература
}

1. Бауман 3. Текучая современность. СПб.: Питер, 2008. 240 с.

2. Pishchik V.I. Psychometric testing methods for measuring type mentality generations // European researcher = Европейский исследователь. 2013. Т. 54, № 7-1. C. 1852-1866. http://www.erjournal.ru/journals_n/1375549025.pdf

3. Pishchik V.I., Gavrilova A.V. Styles of interaction among X-generation teachers and Y-generation students // 6th. World Congress on Psychology and Behavioral Sciences (WCPBS 2016). Spain, Barcelona. pp. 77-79.

4. Schuize G. From situations to subjects: moral discourse in transition // Constructing the New Consumer society / Ed. P. Sulkunen, J. Holmwood, H. Radner, G. Schuize. New York^ Macmillan, 1997. P. 49.

5. Strauss W., Howe, N. Millennials Rising: The next great generation (vintage original). New York, 2009. 432 p.

\section{ВОЗРАСТНОЙ АСПЕКТ СУБЪЕКТНОСТИ ЛИЧНОСТИ}

Полежаева В.А.

Поведение человека с возрастом претерпевает столь же различные изменения, как и его тело. Возрастные особенности образуют определенный комплекс многообразных свойств, характеристик индивида. В отличие от широко варьирующихся индивидуальных особенностей, возрастные изменения отражают такие преобразования, которые происходят в психике большинства представителей данной возрастной категории.

В настоящее время исследование субъектности личности становится приоритетным в психологической науке. Понимание субъекта связывается отношением человека к себе как к деятелю.

Субъектность личности - способность, обеспечивающая человеку возможность осуществлять самоуправление в социальном контексте своего бытия.[2]

Цель практического исследования изучение связь возраста и субъектности личности.

Гипотезы исследования: уровень развития субъектности личности зависит от возраста и изменяется вместе с ним.

Выборка исследования составила 87 человек - 22 человека в возрасте 1617 лет; 21 человек - от 18 до 23 лет; 17 человек - от 24 до 30 лет; 15 человек в возрасте от 31 до 40 лет; 12 человек в возрасте от 41 до 50 лет.

Для выявления уровня субъектности нами был использован опросник «Уровень развития субъектности личности». Среди участников исследования 
не было выявлено низкого уровня развития субъектности личности. У большинства (61\%) уровень выше среднего, 14\% опрошенных со средним уровнем субъектности, $24 \%$ - с высоким уровнем и $1 \%$ - с уровнем ниже среднего.

Среди респондентов всех возрастных групп не было выявлено низкого уровня развития субъектности личности, что говорит о испытуемые не проявляют себя как объект. Уровень ниже среднего выявлен только у участников, возраст которых относится к ранней юности. Испытуемые, находящиеся в возрасте молодости, расцвета и зрелости, всегда используют субъектные стратегии поведения. Также только у исследуемых 16-17лет не было выявлено высокого уровня развития субъектности, так как они эмоционально и физически не стабильны.

Для проверки наших гипотез был использован метод вторичной статистической обработки коэффициент ранговой корреляции Спирмена.

Значение коэффициента, вычисляемого для выявления связи субъектности личности и возраста, оказалась в зоне значимости. Следовательно, связь между уровнем развития субъектности личности и возрастом существует.

Далее нами был использован U-критерий Манна-Уитни для выявления различий уровня развития субъектности в разных возрастных периодах. Значения U-критерия Манна-Уитни для ранней юности и юности и для ранней юности и молодости говорят о значимом изменении в развитии субъектности от ранней юности к юности и от ранней юности к молодости. Значения для возрастных периодов ранняя юность и расцвет, ранняя юность и зрелость, а также молодость и зрелость, лежащие в зоне неопределенности, что говорит об отсутствии критичного изменения в ту или иную сторону. Дальнейшие изменения уровня субъектности имеют статистически незначимые значения.

Исходя из полученных результатов, нами были построены график зависимости субъектности от возраста: от ранней юности уровень развития субъектности личности повышается, к молодости - доходит до своего пика и с дальнейшим взрослением незначительно идет на спад.

Выводы: уровень развития субъектности личности зависит от возраста; уровень субъектности личности изменяется с возрастом: от ранней юности уровень развития субъектности личности повышается, к молодости - доходит до своего пика и с дальнейшим взрослением незначительно идет на спад.

Таким образом, исходя из анализа теоретической литературы, можно считать, что источником развития субъектности личности является пространство деятельности. Механизмами и условиями развития субъектности личности - внутренние противоречия; смещение потребностей личности на созидание; процесс интериоризации; совместная деятельность и общение; включенность индивида в пространство межличностных связей; социально обусловленная направленность быть личностью; развивающая деятельность; самотворение человека своей личности; личностные способности.

Исходя из результатов нашей работы, мы можем сделать вывод, что необходимо развивать пространство школы для раннего развития субъектности личности. 


\section{Литература}

1. Гамезо М.В., Домашенко И.А. Атлас по психологии: Информ.метод. Пособие к курсу «Психология человека»: - М.: Пед. общ-во России, 1999. - 397 c.

2. Ленглер О. А. Субъектность человека: психолого-педагогические основы [Текст] / О. А. Ленглер // Молодой ученый. — 2012. — №11. — С. 440442.

3. Петровский А.В., Ярошевский М.Г. Психология. Учеб.для вузов. М.: Издат. Центр «Академия», 2000. -512 с.

4. Попов Л.М. Психологический механизм и зоны развития субъекта / Л.М.Попов // Субъектный подход в инновационной подготовке педагогапсихолога. Под ред. Ф.Г.Мухаметзяновой. - Казань: ЮЛАКС, 2006. - С. 21-33.

5. $\quad$ Психология прогнозирования: успехи в познании будущего. - СПб.: Речь,2003. - 352 с.

\section{ИССЛЕДОВАНИЕ СТРУКТУРЫ ЖИЗНЕННОГО ПРОСТРАНСТВА ЛИЧНОСТИ}

Проскурякова Е.А.

Аннотация: Субъективное ощущение жизненного пространства личности является одной из важных составляющих самоощущения человека, влияющего на уровень самооценки, настроение, мотивационно-регулятивную функцию и другие основные параметрические характеристики личности. Данное исследование призвано рассмотреть факторы, влияющие на удовлетворенность личности ее жизненным пространством и отношение к нему в целом. В соответствии с нашей гипотезой, к этим факторам относятся такие личностные свойства, как психологическое благополучие, суверенность психологического пространства и смысложизненные ориентации.

Удовлетворенность местом проживания и своим жизненным пространством в целом одна из основных составляющих человеческого самоощущения. Субъективное ощущение удовлетворенности жизнью прямо влияет на мотивацию, настроение человека и его жизнедеятельность.

Тема отношения к жизненному пространству является актуальной, поскольку позволяет приблизиться к пониманию современного человека как субъекта и автора своего мира, создателя своего жизненного пространства, дает возможность проанализировать взаимоотношения личности и среды с различных сторон.

Жизненное пространство личности - это все, что нас окружает. Это “человек и психологическая среда, как она существует для него" [2, с. 77] по определению К. Левина - одного из ключевых исследователей жизненного пространства, а также автора теории поля, показывающей взаимоотношения человека с окружающей его средой и акцентирующей внимание именно на моменте взаимодействия, важности изучения человека в ситуации, а не отдельно от нее. 